\title{
Swafoto Narsistik dan Harga Diri Remaja
}

\author{
MUHAMMAD ARIEF NAJIB*, ANGGA SUGIARTO \& ERNA ERAWATI \\ Prodi D4 Keperawatan Magelang Poltekkes Kemenkes Semarang
}

\begin{abstract}
ABSTRAK
Swafoto yang narsistik adalah foto diri yang di bagikan melalui media sosial sedikitnya dua foto per minggu, dengan memiliki kepercayaan diri secara berlebihan, merasa lebih unggul dengan maksud mengeksplore diri ke publik, guna mendapat perhatian yang selalu mengejar pengakuan dari orang lain. Swafoto merupakan salah satu trend dikalangan remaja yang digunakan untuk pengembangan harga diri. Penelitian ini bertujuan untuk mengidentifikasi hubungan swafoto yang narsistik dengan harga diri remaja. Desain penelitian ini menggunakan kuantitatif observasional analitik cross sectional. Hipotesis yang diajukan ada hubungan swafoto yang narsistik dengan harga diri remaja. Adapun subjek penelitian memiliki karakteristik responden dengan intensitas mengunggah foto swafoto ke media sosial dua foto perminggu, dengan jumlah 101 responden. Teknik sampling menggunakan sistem purposive sampling. Hasil penelitian menunjukkan adanya hubungan swafoto yang narsistik dengan harga diri remaja $(\tau=.534$, nilai $\mathrm{p}<.01)$.
\end{abstract}

Kata kunci: harga diri, narsistik, remaja, swafoto

\begin{abstract}
Swafoto narcissist is self-portraits which are distributed via social media at least two photos per week, to have the confidence to excess, to feel superior to explore yourself, in order to get the limelight that always pursue recognition from others. Swafoto is a trend among adolescents who are used for the development of self-esteem. Aim to identification the correlation of narcissistic swafoto with adolescent self-esteem. The design of this study is quantitative analytical observational cross-sectional. Subjects of this study have the characteristics of respondents with intensity upload swafoto photos to social media two photos per week with 101 respondents narcissistic photos swafotos. Purposive technique sampling used in this research. The result shows a moderate correlation between narcissistic swafoto with adolescent self-esteem $(\tau=.534, p$ value<.01).
\end{abstract}

Keywords: adolescence, narcissistic, self-esteem, selfie

INSAN Jurnal Psikologi dan Kesehatan Mental, tahun, Vol. 2(2), 103-110, doi: 10.20473/jpkm.v2i22017.103-110 Dikirimkan: 20 Juni 2017 Diterima: 13 Juli 2018 Diterbitkan: 18 Juli 2018

Editor: Dewi Syarifah

*Alamat korespondensi: Jalan Perintis Kemerdekaan Magelang, Jawa Tengah 56115. Pos-el: m.arief.najib@gmail.com

Naskah ini merupakan naskah dengan akses terbuka dibawah ketentuan the Creative Common Attribution License (http://creativecommons.org/licenses/by/4.0), sehingga penggunaan, distribusi, reproduksi dalam media apapun atas artikel ini tidak dibatasi, selama sumber aslinya disitir dengan baik. 


\section{P E N D A H U L U A N}

Perkembangan zaman yang pesat membuat teknologi juga berkembang. Perkembangan tersebut memunculkan berbagai fenomena yang terdapat dikehidupan, apalagi banyak bermunculnya aplikasi yang memudahkan untuk melakukan berbagai hal. Salah satu fenomena kemajuan teknologi adalah swafoto, yang sekarang ini sedang menjadi tren, khususnya di kalangan remaja. Remaja rentang usia 11-14 tahun menghabiskan lebih dari 6.5 jam per hari untuk media. Mereka online hampir 8 jam per hari dari konten media, karena mereka menggunakan beberapa media secara bersamaan (Lavesque, 2007).

Remaja mulai mencapai kematangan fisik, sosial dan psikologis melalui masa-masa pencarian identitas diri dan pengakuan diri. Oleh karena itu, remaja memerlukan pengembangan relasi dirinya melalui pengembangan harga diri (Padmomartono, 2014). Apabila identitas dan pengakuan diri sudah sesuai, maka remaja memiliki harga diri yang tinggi. Namun, harga diri yang tinggi pada remaja cenderung berimplikasi timbulnya sifat narsistik, yaitu memperhatikan diri sendiri secara berlebihan, memiliki kepercayaan diri berlebih, merasa lebih unggul dari orang lain, haus akan pengakuan dirinya terhadap orang lain. Salah satu faktor yang mempengaruhi kecenderungan narsistik adalah harga diri (Clarke, Karlov \& Neale, 2014). Sifat narsistik remaja berbanding lurus dengan keinginan remaja untuk melakukan swafoto.

Keinginan untuk swafoto dihadapan kamera menyebabkan remaja merasa lebih percaya diri. Hal ini didukung oleh perkembangan fasilitas kamera yang canggih, yang selanjutnya diunggah ke jejaring sosial seperti Instagram, Facebook, Path, Twitter dan sebagainya, yang dapat memenuhi ke arah aktualisasi para remaja. Oleh karena itu, mereka merasa bahwa swafoto sebagai media yang dapat menyalurkan kebutuhan mereka. Sebuah riset yang dilakukan pada tanggal 26-29 Juli 2013 antara usia 18-24 tahun oleh lembaga Opinium di Inggris terhadap 2005 responden, menunjukkan bahwa ada lebih dari satu juta swafoto dibuat dalam sehari (Nasrullah, 2016).

Suk (2014) membuat grafik mengenai swafoto yang diberi nama selfiegraphic. Terdapat lebih dari satu juta swafoto dengan tagar swafoto (\#selfie) yang diambil setiap harinya, dari 50\% laki-laki dan 52\% perempuan. Hasil pengunggahan swafoto yang paling banyak di jejaring sosial adalah Facebook 48\%, Whatsapp dan Text 27\%, Twitter 9\%, Instagram 8\%, Snapchat 5\%, dan Pinterest 2\%. Hal tersebut juga dilakukan oleh Wilson (2014) dengan membuat peringkat dari 100 kota pengambilan swafoto terbanyak dengan membuat basis data dari 400.000 foto Instagram yang diteliti dengan tagar swafoto (\#selfie) serta menyertakan koordinat geografiknya. Tercatat 459 kota yang menggunakan swafoto di dunia. Tiga peringkat dari 100 peringkat yang dibuat adalah Kota Makati dan Pasiq di Filipina, mendapat peringkat pertama dengan pengambilan swafoto 258 dari populasi pengambilan swafoto di dunia, selanjutnya di Manhatan, New York, sebanyak 202 pengambilan swafoto, dan yang ketiga yaitu kota Miami, Florida, sebesar 155 pengambilan swafoto (Suk, 2014).

Menurut Nasrullah (2016), ada beberapa alasan seseorang melakukan swafoto. Pertama, sebagai wujud mengekplorasi diri sendiri dengan tidak hanya terfokus pada penampilan diri si pengguna saja, namun juga merupakan upaya untuk menunjukkan diri si pengguna dalam aktivitas sehari-hari mereka, seperti apa yang sedang ia lakukan saat ini. Kedua, swafoto juga merupakan keterbukaan diri pengguna di media sosial. Dampak dari keterbukaan diri tersebut, interaksi dan komunikasi antara si pengguna dengan pengguna lain semakin erat, sehingga pengunggahan swafoto dapat menambah jalinan pertemanan. Ketiga, swafoto merupakan salah satu bentuk narsisme digital guna menarik kesan pengguna media sosial lain.

Nasrullah (2016) mengatakan swafoto merupakan sebuah budaya siber yang disepakati dengan perspektif politik, ekonomi, pendidikan, psikologi, bisnis, dan agama. Akan tetapi awal dari timbulnya swafoto adalah kehadiran teknologi yang dimana memberikan ruang bagi si pengguna untuk mengakses 
diri melalui jaringan sosial, guna untuk mengkonstruksikan dirinya sendiri. Alasan lain dari penggunaan swafoto adalah dapat digunakan untuk pendokumentasian aktivitas diri meraka pribadi, mengabadikan momen dalam berbagai suasana dan ekspresi saat ia berkumpul dengan teman maupun sendiri. Apalagi sekarang ini semakin didukung oleh alat bantu berupa tongkat narsis atau biasa disebut tongsis, untuk mempermudah pengguna swafoto dalam memotret diri sendiri tanpa bantuan orang lain. Dengan tongsis si pengguna swafoto dapat memoto dirinya dimana saja, posisi apa saja, dan waktu kapan saja. Sehingga, saat ini manusia dijuluki dengan homus photographicus (Farias dalam Nasrullah, 2016).

Seiring berjalannya waktu, swafoto mempunyai dampak positif dan negatif. Swafoto dapat memberikan dampak positif apabila dapat digunakan secara baik dan benar. Contohnya, ketika ia mengunggah foto mengenai cara hidup sehat si pengguna, maka dapat bermanfaat bagi diri sendiri dan orang lain. Si pengguna juga terlihat lebih percaya diri, senang, dan dapat menyalurkan hobi. Selain itu, politik menjadikan swafoto sebagai pengabadian suatu kegiatan dan alasan keaslian produksi, melihat, atau diedarkan. Hal ini mungkin untuk alasan bahwa swafoto berfungsi baik sebagai praktek kehidupan sehari-hari dan sebagai obyek politisasi wacana tentang bagaimana orang harus mewakili, mendokumentasi, dan berbagi perilaku mereka (Senft \& Baym, 2015).

Dampak negatif dari swafoto itu sendiri adalah sifat narsisme, yaitu terlalu berlebihan mengunggah foto diri sendiri ke media sosial guna ingin dipuji dan mendapat pengakuan dari orang lain. Selain itu juga unggahan foto yang terlalu sering berdampak pada diri si pengguna sendiri, dimana orang lain beresiko untuk tidak menyukai dirinya. Seperti kasus Bowman yang mendapati perhatian dari tabloid Inggris The Daily Mail, ketika ia mencoba bunuh diri, konon karena dia tidak puas dengan kualitas swafotonya (Senft \& Baym, 2015).

Penelitian yang dilakukan oleh Baumeister, Bushman, dan Campbell (2000) bahwa individu yang narsistik memiliki harga diri yang tinggi, namun penelitian lain mengenai narsistik dengan harga diri yang dilakukan oleh Barry, Frick dan Killian (2003) yang menemukan bahwa interaksi antara narsisme yang tinggi berkaitan dengan harga diri yang rendah.

Fenomena swafoto narsistik yang semakin membudaya dan berdasarkan penelitian dari beberapa ahli mengenai hubungan narsistik dengan harga diri, membuat peneliti tertarik untuk meneliti mengenai swafoto. Oleh karena itu peneliti mengajukan rumusan masalah penelitian sebagai berikut; apakah ada hubungan swafoto yang narsistik dengan harga diri remaja? Adapun tujuan penelitian yaitu mengetahui; (a) distribusi frekuensi pelaku swafoto yang narsistik remaja, mengetahui tingkat swafoto yang narsistik remaja; (b) mengetahui tingkat harga diri pelaku swafoto yang narsistik remaja; dan (c) hubungan antara swafoto yang narsistik dengan harga diri remaja.

\section{E T ODE}

\section{Desain Penelitian}

Penelitian ini bertujuan untuk menginvestigasi korelasi antara swafoto yang narsistik dengan harga diri. Oleh karena itu, berdasarkan jenisnya, penelitian ini merupakan penelitian kuantitatif cross sectional dengan desain penelitian survei sosial.

\section{Partisipan}

Populasi pada penelitian ini adalah seluruh Siswa di SMP Negeri 1 Garung Kabupaten Wonosobo yang melakukan swafoto yang narsistik. Subjek penelitian ini sebanyak 101 responden yang melakukan swafoto yang narsistik minimal mengunggah dua foto per minggu. Adapun teknik sampling 
menggunakan sistem purposive sampling, yang artinya teknik penentuan sampel dengan kriteria tertentu.

\section{Pengukuran}

Variabel independen penelitian ini adalah swafoto yang narsistik. Alat ukur yang digunakan menggunaka skala Narcisstic Personality Inventory (NPI). Peneliti menggunakan 3 aspek dari 7 aspek yang terdiri dari 15 item. Untuk masing-masing pertanyaan dari nomor berikut ini yang menjawab $\mathrm{A}$, diberi poin 1 yaitu 4, 6, 7, 11,12, 15 dan pertanyaan pada nomor 1, 2, 3, 5, 8, 9, 10,13, 14 yang menjawab B diberi poin 1. Pengkategorian narsistik dibagi menjadi dua, yaitu narsistik tinggi dan narsistik rendah. Untuk mendapatkan gambaran narsistik subyek, dilakukan perhitungan nilai rata-rata dari skor total skala narsistik, yang dimana dikatakan narsistik tinggi dengan nilai skor $\geq$ rerata dan narsistik rendah dengan nilai skor $\leq$ rerata.

Variabel dependen penelitian ini adalah harga diri. Alat ukur yang digunakan Rosenberg Self-Esteem scale (RSES). Skala ini memuat 10 butir pertanyaan yang menggunakan format Likert dengan 4 pilihan jawaban yang di skor 1 hingga 4. Kategori respons yang diberikan adalah: sangat setuju; setuju; tidak setuju dan sangat tidak setuju. Skala ini bersifat favorable dan unfavorable. Pengkategorian harga diri dibagi menjadi dua, yaitu harga diri tinggi dan harga diri rendah. Semakin tinggi skor yang didapat, maka semakin tinggi tingkat harga diri. Untuk mendapatkan gambaran harga diri subyek, dilakukan perhitungan nilai rata-rata dari skor total skala harga diri. Apabila nilai skor harga diri $\geq$ rerata, maka harga diri tinggi, sebaliknya nilai skor $\leq$ rerata, maka harga diri rendah.

\section{Analisis Data}

Data yang terkumpul dianalisis dengan teknik statistik deskriptif, untuk mengkategorisasi kedua variabel penelitian yang diukur, sedangkan hipotesis penelitian diuji dengan menggunakan teknik korelasi Kendall's tau dengan menggunakan SPSS versi 16.

\section{HAS IL PENELITIAN}

\section{Data Deskriptif}

Karakteristik pelaku swafoto yang narsistik berdasarkan rentang umur mayoritas responden berumur 13 tahun, yaitu sebanyak 33 (32.7\%) responden, sedangkan paling rendah sebanyak 4 (4\%) responden berumur 12 tahun. Pelaku swafoto yang narsistik berdasarkan jenis kelamin mayoritas berjenis kelamin perempuan yaitu sebanyak $69.3 \%$ atau 70 responden.

Skor nilai maksimum skala NPI adalah 11 dengan nilai rata-rata 4.74. Sedangkan rata-rata nilai skala RSES adalah 29.37 dengan nilai minimum 17. Untuk mengetahui kategori narsitik dapat ditentukan dengan mengukur skala rata-rata skor total dari NPI. Hasil rata-rata NPI adalah 4.74. Oleh karena itu apabila dikatakan narsistik tinggi apabila skor $\geq$ rerata, dan sebaliknya apabila dikatakan narsistik rendah apabila skor $\leq$ rerata. Begitu juga dengan mengetahui kategori harga diri dapat ditentukan dengan mengukur skala rata-rata skor total dari RSES. Oleh karena itu dikatakan harga diri rendah apabila skor $\leq$ rerata, dan sebaliknya apabila harga diri tinggi skor $\geq$ rerata. Pengkategorian narsistik dibagi menjadi dua, yaitu narsistik tinggi dan narsistik rendah. Dimana dengan jumlah 51 responden memiliki narsistik tinggi. Karakteristik harga diri dibagi menjadi dua, yaitu harga diri tinggi dan harga diri rendah. Dimana dengan persentase 60.4\% memiliki harga diri yang tinggi. 


\section{Uji Hipotesis}

Hubungan antara swafoto yang narsistik dengan harga diri dapat dilihat dari hasil nilai signifikansi Kendall's tau yang dihasilkan, dengan ketentuan bahwa kedua variabel yang diuji mempunyai hubungan dengan nilai $\mathrm{p}<.05$. Berdasarkan hasil analisis dapat disimpulkan bahwa ada hubungan yang positif dan sedang antara swafoto yang narsistik dengan harga diri $(\tau=.534$, nilai $\mathrm{p}<.01)$.

\section{I S K U S I}

Pelaku swafoto yang narsistik pada penelitian ini yang dijadikan subjek adalah responden yang mempunyai rentang umur 11-16 tahun, umur tersebut merupakan masa remaja awal dan madya (Mansur dan Budiarti, 2011). Mayoritas responden pada penelitian ini berumur 13 tahun dan paling sedikit berumur 12 tahun. Pada masa tersebut, remaja mengalami perubahan psikologis seperti krisis identitas dan sangat memperhatikan penampilan (Batubara, 2010). Seperti halnya yang dikatakan oleh Rumaisa, Rita dan Hafiz (2015) bahwa kecenderungan narsistik merupakan salah satu perkembangan kepribadian pada tahap remaja. Minat swafoto pada remaja terjadi karena keinginan diri sendiri atau faktor lingkungan lainnya. Sehingga salah satu cara untuk mendapatkan pengakuan dan keberadaan yaitu dengan eksis di media sosial (Anshori, dkk., 2016).

Responden juga mempunyai media sosial, dan sedikitnya mengunggah minimal dua foto dalam seminggu. Karakteristik responden lebih besar berjenis kelamin perempuan, yaitu sebanyak $68.3 \%$ atau 69 responden. Maka dapat diketahui bahwa perempuan memberikan kontribusi lebih besar dibandingkan laki-laki terhadap perilaku swafoto yang narsistik pada penelitian ini. Hal tersebut senada dengan hasil penelitian Puspitasari (2016), mengungkapkan bahwa perempuan memiliki sumbangan lebih besar dari pada laki-laki terhadap perilaku swafoto yang narsistik. Philipson dalam Ryan, dkk. (2008) mengatakan salah satu faktor penting dalam mengekspresikan narsistik adalah jenis kelamin. Laki-laki maupun perempuan yang narsistik, masing-masing memiliki kebutuhan yang sama, seperti haus akan pemujaan dengan merasa lebih hebat, dan kebutuhan tersebut memiliki tujuan yang sama walaupun cenderung didapatkan dengan cara yang berbeda (Goodman \& Leff, 2012).

Hasil analisis tingkat swafoto yang narsistik diketahui bahwa responden penelitian sebagian besar mempunyai narsistik yang tinggi dengan persentase $50.5 \%$ atau 51 responden, sedangkan 50 (49.5\%) responden masuk ke dalam kategori narsistik rendah. Hal ini dapat diartikan bahwa responden penelitian tidak semuanya memiliki sifat narsistik yang tinggi. Faktor-faktor yang mempengaruhi tinggi rendahnya narsistik seseorang, adalah faktor biologis (jenis kelamin, usia, fungsi hormonal dan struktur fisik lainnya), faktor psikologis seperti harapan dan tujuan yang kurang realistis dan faktor sosiologis (Lubis dalam Apsari, 2012).

Remaja yang memiliki narsistik tinggi ia merasa bahwa dirinya baik, merasa spesial, selalu ingin dipuji, merasa dirinya luar biasa, melakukan apa saja dengan berani, suka menjadi pusat perhatian, mencoba untuk memamerkan, akan memulai gaya dan mode baru, dan suka terhadap penampilan fisiknya. Hal ini sejalan dengan yang dikemukakan oleh Vazire, dkk. (2008) mengatakan bahwa narsistik sebagai wujud penampilan fisik seseorang, seperti kepentingan tentang penampilan mereka, keinginan untuk menjadi pusat perhatian dan perubahan penampilan fisik dalam usaha pencarian status sosial.

Remaja yang memiliki narsistik rendah kadang-kadang merasa malu saat orang lain memujinya, ia merasa lebih buruk dari orang lain, cenderung menjadi orang yang cukup berhati-hati, tidak suka memamerkan, kurang percaya diri dan tidak peduli tentang gaya dan mode baru. Hal tersebut sejalan dengan yang dikatakan oleh Buffardi dan Campbell (2008) bahwa seseorang dengan narsistik rendah, terlihat kurang menarik secara fisik dalam foto mereka, dan kurang mempromosikan dirinya kepada orang lain.

INSAN Jurnal Psikologi dan Kesehatan Mental

2018, Vol. 2(2), 103-110

doi: $10.20473 /$ jpkm.v2i22017.103-110 
Hasil analisis diketahui bahwa responden mayoritas memiliki harga diri tinggi yaitu 61 (60.4\%) responden, sedangkan $39.6 \%$ atau sebanyak 40 responden memiliki harga diri rendah. Beberapa faktor yang mempengaruhi harga diri adalah usia dan jenis kelamin (McLoed \& Owens, Powell dalam Myers, Willse \& Villalba, 2011). Tinggi rendahnya harga diri tidak hanya dipengaruhi oleh swafoto saja. Adapun faktor lain yang mempengaruhi harga diri, yaitu jenis kelamin, inteligensi, kondisi fisik, lingkungan keluarga, dan lingkungan sekitar (Ghufron, 2011). Begitu juga dengan Trumpeter, dkk. (2008) mengatakan bahwa kemampuan interpersonal, dukungan sosial, jenis kelamin, dan kelas sosial merupakan faktor yang berpengaruh dalam pembentukan harga diri.

Remaja yang memiliki harga diri yang tinggi secara keseluruhan memiliki rasa cukup berharga, menerima keadaan dirinya seperti apa adanya, mampu mengerjakan sesuatu seperti apa yang dilakukan orang lain, merasa puas terhadap dirinya dan berharap dapat lebih dihargai. Hal ini seperti yang dikemukakan oleh Coopersmith dalam Ghufron (2011) bahwa harga diri mempunyai tiga aspek, yaitu rasa diterima, rasa mampu, serta rasa dibutuhkan.

Remaja pada penelitian ini yang memiliki harga diri rendah merasa bahwa dirinya orang yang gagal, tidak begitu bangga pada dirinya sendiri, sering merasa tidak berguna, dan kadang-kadang merasa bahwa dirinya tidak baik. Hal tersebut sejalan dengan yang dikatakan oleh Baumeister, Bushman, dan Campbell (2000) bahwa seseorang yang memiliki harga diri yang rendah merasa tidak pasti dan bingung tentang diri mereka sendiri, cenderung menghindari risiko dan potensi akan kerugian, pemalu, sederhana, emosional labil seperti memiliki kecenderungan ke arah depresi dan cemas, dan kurang percaya diri dalam diri mereka.

Temuan penelitian ini mendukung hipotesis bahwa ada hubungan antara swafoto yang narsistik dengan harga diri, sejalan dengan temuan penelitian Clarke, Karlov dan Neale (2014) mengemukakan hal yang berbeda bahwa salah satu faktor yang mempengaruhi kecenderungan narsistik adalah harga diri. Swafoto yang narsistik akan mempengaruhi tingkat harga diri remaja. Hal ini didukung dari hasil analisis bahwa remaja yang memiliki tingkat narsistik tinggi mempunyai harga diri yang tinggi, sedangkan remaja yang mempunyai tingkat narsistik rendah mempunyai harga diri yang rendah. Hasil ini dapat diartikan bahwa semakin tinggi tingkat swafoto yang narsistik pada remaja, maka semakin tinggi pula tingkat harga dirinya.

Swafoto yang narsistik merupakan salah satu hal yang dilakukan remaja guna mengembangkan harga diri. Dengan swafoto, remaja dapat mengeksplorasi diri mereka guna memenuhi kebutuhan seperti kasih sayang atau pujian dari orang lain, berdiri sendiri yang artinya remaja mampu melakukan tugastugas apa yang dikerjakan oleh orang dewasa, pengakuan dari orang lain, dan untuk dihargai. Hal tersebut disebabkan karena salah satu sifat karakteristik masa remaja adalah menarik perhatian lingkungannya (Mansur \& Budiarti , 2011). Masa remaja membutuhkan pengembangan hubungan sosial melalui pengembangan harga diri (Padmomartono, 2014). Berusaha mengeksplorasi diri mereka kepada orang lain dengan melakukan swafoto yang di upload ke media sosial yang didasari pada keterbukaan diri. Hal tersebut menjadikan interaksi dan komunikasi antara si pengguna dengan pengguna lain semakin erat, sehingga dari pengunggahan swafoto dapat menambah jalinan pertemanan yang dimana pengguna lain dapat mengetahui si pemilik akun media sosial (Nasrullah, 2016).

Remaja yang memiliki narsistik tinggi merasa bahwa dirinya itu baik, luar biasa, melakukan apa saja dengan berani, suka terhadap penampilan fisiknya. Begitu juga dengan remaja yang memiliki harga diri yang tinggi secara keseluruhan ia merasa dirinya cukup berharga, mampu mengerjakan sesuatu seperti apa yang dikerjakan orang lain, berharap lebih dapat dihargai.

Hal ini diperkuat oleh penelitian yang dilakukan oleh Puspitasari (2016) tentang pengaruh harga diri, hubungan romantis, dan pengambilan risiko terhadap perilaku swafoto yang narsistik, yang menunjukan bahwa terdapat pengaruh yang signifikan antara harga diri dengan swafoto yang narsistik.

INSAN Jurnal Psikologi dan Kesehatan Mental

2018, Vol. 2(2), 103-110

doi: 10.20473/jpkm.v2i22017.103-110

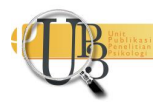


Penelitian ini sama dengan yang dilakukan oleh Apriliani (2015) yang menunjukkan bahwa terdapat hubungan negatif antara narsisme facebooker dengan self esteem. Begitu juga penelitian yang dilakukan oleh Baumeister, Bushman, dan Campbell (2000) bahwa individu yang narsistik memiliki harga diri yang tinggi.

\section{S I M P U L A N}

Berdasarkan hasil analisis data dan pembahasan pada bab sebelumnya, maka dapat ditarik kesimpulan bahwa ada hubungan yang signifikan antara swafoto yang narsistik dengan harga diri remaja siswa SMP Negeri 1 Garung Kabupaten Wonosobo. Pada penelitian ini perilaku swafoto yang narsistik mayoritas memiliki narsistik yang tinggi dan sebagian besar memiliki harga diri yang tinggi. Tingkat swafoto yang narsistik akan mempengaruhi tingkat harga diri remaja. Hal ini didukung dari hasil analisis bahwa remaja yang memiliki tingkat narsistik tinggi mempunyai harga diri yang tinggi, sedangkan remaja yang mempunyai tingkat narsistik rendah mempunyai harga diri yang rendah. Hasil ini dapat diartikan bahwa semakin tinggi tingkat swafoto yang narsistik pada remaja, maka semakin tinggi pula tingkat harga dirinya.

\section{P USTAKA ACUAN}

Anshori H., Ariani A., Rumaisa. (2016). Hubungan Minat Selfie Terhadap Kecenderungan Gangguan Kepribadian Narsistik Pada Siswa-Siswi Di SMPN 7 Kelas VII Banjarmasin. Naskah tidak dipublikasikan. Fakultas Ushuluddin dan Humaniora, IAIN Antasari Banjarmasin.

Apriliani F. (2015). Narsisme Facebooker Ditinjau dari Self-Esteem. Jurnal Guidena, 1-19.

Apsari F. (2012). Hubungan Antara Kecenderungan Narsisme Dengan Minat Membeli Kosmetik Merek Asing Pada Pria Metroseksual. Talenta Psikologi, 1(2), 198.

Barry, C. T., Frick, P. J., \& Killian, A. L. (2003). The relation of narcissism and self-esteem to conduct problems in children: A preliminary investigation. Journal of Clinical Child and Adolescent Psychology, 32(1), 139-152.

Batubara, J. R. (2016). Adolescent development (perkembangan remaja). Sari Pediatri, 12(1), 21-9.

Baumeister, R. F., Bushman, B. J., \& Campbell, W. K. (2000). Self-esteem, narcissism, and aggression: Does violence result from low self-esteem or from threatened egotism? Current directions in psychological science, 9(1), 26-29.

Buffardi, L. E., \& Campbell, W. K. (2008). Narcissism and social networking web sites. Personality and Social Psychology Bulletin, 34(10), 1303-1314.

Clarke, I. E., Karlov, L., \& Neale, N. J. (2015). The many faces of narcissism: Narcissism factors and their predictive utility. Personality and Individual Differences, 81, 90-95.

Ghufron M.N. \& Risnawita R.S. (2010). Teori-Teori Psikologi. Yogyakarta: Ar Ruzz Media.

Goodman CL., \& Leff B. (2012). The Everything Guide to Narcissistic Personality Disorder. Massachusetts: Adams Media.

Levesque, R. J. (2007). Adolescents, media, and the law: What developmental science reveals and free speech requires. Oxford: Oxford University Press.

Mansur H \& Budiarti T. (2011). Psikologi Ibu Dan Anak. (Ed 2). Jakarta: Salemba Medika.

INSAN Jurnal Psikologi dan Kesehatan Mental

2018, Vol. 2(2), 103-110

doi: $10.20473 /$ jpkm.v2i22017.103-110 
Myers, J. E., Willse, J. T., \& Villalba, J. A. (2011). Promoting self-esteem in adolescents: the influence of wellness factors. Journal of Counseling \& Development, 89(1), 28-36.

Nasrullah, R. (2016). Media Sosial: Perspektif Komunikasi, Budaya dan Sosioteknologi. (Ed 2). Bandung: Simbiosa Rekatama Media.

Padmomartono, S. (2014). Konseling Remaja. Yogyakarta: Penerbit Ombak.

Puspitasari M. (2016). Pengaruh Harga Diri, Hubungan Romantis, Dan Pengambilan Risiko Terhadap Perilaku Selfie Yang Narsistik. Diunduh dari: http://www.academia.edu/26008982/Pengaruh_Harga_Diri_Hubungan_Romantis_dan_Pengam bilan_Risiko_terhadap_Perilaku_Selfie_yang_Narsistik.

Rumaisa, Arianti R, dan Anshori H. (2015). Hubungan Minat Selfie Terhadap Kecenderungan Gangguan Kepribadian Narsistik Pada Siswa-Siswi di SMPN 7 Kelas VIII Banjarmasin, 1-81. Diunduh dari: http://idr.iain-antasari.ac.id/id/eprint/5302/

Ryan, K. M., Weikel, K., \& Sprechini, G. (2008). Gender differences in narcissism and courtship violence in dating couples. Sex Roles, 58(11-12), 802-813.

Senft, T. M., \& Baym, N. K. (2015). Selfies introduction What does the selfie say? Investigating a global phenomenon. International Journal of Communication, 9, 19.

Suk T. (2014). Selfie Infographic "Selfiegraphic" Facts And Statistics. Diakses pada tanggal 5 Desember 2016 dari http://techinfographics.com/selfie-infographic-selfiegraphic-facts-and-statistics/.

Trumpeter, N. N., Watson, P. J., O'Leary, B. J., \& Weathington, B. L. (2008). Self-functioning and perceived parenting: Relations of parental empathy and love inconsistency with narcissism, depression, and self-esteem. The Journal of Genetic Psychology, 169(1), 51-71.

Vazire, S., Naumann, L. P., Rentfrow, P. J., \& Gosling, S. D. (2008). Portrait of a narcissist: Manifestations of narcissism in physical appearance. Journal of Research in Personality, 42(6), 1439-1447.

Wilson C. (2014). The Selfiest Cities In The World: Time's Definitive Ranking. Diakses pada tanggal 6 November 2016 dari http://time.com/selfies-cities-world-rankings/. 